AFRREV, 10 (1), S/NO 40, JANUARY, $2016 \mid 1$

African Research Review

An International Multidisciplinary Journal, Ethiopia

Vol. 10(1), Serial No.40, January, 2016:1-16

ISSN 1994-9057 (Print)

ISSN 2070--0083 (Online)

Doi: http://dx.doi.org/10.4314/afrrev.v10i1.1

\title{
Practices and Challenges in the Provision of Pre-Primary Education in Tanzania
}

\author{
Mghasse, Ngikundael Enos \\ District School Quality Assurance Office \\ Monduli; Arusha - Tanzania \\ Email: mghassengikundaeli@yahoo.co.uk \\ Cell Phone: +255754 688298 \\ \& \\ William, Francis \\ Lecturer, College of Education, University of Dodoma \\ P. O Box 523, Dodoma-Tanzania \\ kyambo20001@yahoo.com \\ +255755827276, +255713896691
}

\begin{abstract}
This study focused on exploring issues in the provision of pre-primary education in Monduli district in Arusha region-Tanzania. The specific objectives were to assess the current practices in the provision of pre-primary education in Tanzania, to investigate the challenges that encountered the provision of pre-primary education and then suggest appropriate strategies for the provision of pre-primary education in Tanzania. The study used both qualitative and quantitative approaches in data collection and analysis. Data were collected from the participants through interviews, questionnaire and documentary review. The findings from the study showed that Head Teachers faced multiple challenges in managing pre-primary education, including shortage of
\end{abstract}

Copyright (C) IAARR, 2007-2016: www.afrrevjo.net

Indexed African Journals Online: www.ajo.info 
classrooms, shortage of qualified teachers and lack of teaching and learning materials. This study concludes that only few schools in Monduli district provided pre-primary education due to some challenges including inadequate classrooms, inadequate teaching and learning materials, absence of qualified teachers, long distance from schools to home and readiness of parents to enrol students. Based on the findings, it is recommended that policy planners should clarify the importance of preparations for pre-primary schooling. The government should furnish pre-primary classes with relevant facilities including books, tables, chairs teaching and learning materials, and qualified teachers.

\section{Introduction}

The Jomtien World Declaration on Education for All (EFA) asserted that learning begins at birth (UNESCO, 2000). This calls for early childhood care and early child education that is provided through involvement of families, communities, or institutional programs. It is through quality education that people can create a strong and competitive economy which can effectively cope with the challenges of development and which can easily and confidently be adapted to the changing market and technological conditions in the region and global economy (Louis and Miles, 1990). Hallinger (1992) asserts that one way to create education change is to improve pre-primary education which is the base and the most prominent aspect to be considered for the excellence achievement of students when entering to other levels of education. Therefore, pre-primary education has to be well supported by the government and stakeholders for the realization of quality education. The structure of the formal education and training system in Tanzania constitutes of 2 years of pre-primary education, 7 years of primary education, 4 years of secondary (Ordinary Level), 2 years of secondary (Advanced Level), and a minimum of 3 years of university education (URT, 1995). Though Education and Training Policy-ETP of (1995) stipulates that the Government should put more effort in developing the entire education spectrum which include nursery, day-care centers and kindergartens as part of formal education and training system. The general purpose of pre-primary education is to prepare children physically, emotionally, socially and mentally to enter Grade I of primary school education. This preparation is considered as the foundation for further psychological development (EFA, 2000).

The developed world has sufficient arrangements for pre-primary education. Most OECD (Organization for Economic Co-operation and Development) countries have at least two years of free pre-primary education (UNESCO, 2007). Worldwide, the gross enrolment ratio in pre-primary education has tripled since 1970's. Almost 124 million children were enrolled in pre-primary education in 2004, which was $10.7 \%$ increase over 1999 (UNESCO, 2007). However, this increase did not occur equally throughout the world. Enrolment in schools is expected to increase steadily as more pre-school classes are opened on government primary school premises. Regardless of 
this argument, participation in pre-primary education is unevenly distributed in the world. It is highest in developed and countries in transition than in underdeveloped countries. It is also high in Latin America, the Caribbean, in East Asia and the Pacific. It remains very low in Sub-Saharan African countries which stand at 14\% and Arab states which stand at $17 \%$ (EI, 2008).

In Tanzania, the total enrolment in pre-primary education dropped by $3.2 \%$ from 1,069,208 in the year 2011 to 1,034,729 in the year 2012 which implies that there is a decrease in participation in pre-primary education (URT, 2012). In the year 2012, the NER percentage of official school age (5-6 years) pupils enrolled in pre-primary education was $39.9 \%$, whereas, the GER (total enrolment) was $41.8 \%$ of school age population. Both GER and NER are showing a decreasing trend as compared to previous years (URT, 2012). In Monduli District the provision of pre-primary education is in a great challenge. This situation makes this program almost dormant. Issues such as distance from school to pupils' homestead, cultural attitudes, and modes of production, ignorance, negligence, priority and lack of infrastructures may contribute to poor provision of pre-primary education (BED, 2009).

Sustainable pre-school education gives a child solid foundation in the primary schooling (Osakwe, 2009). Notwithstanding the importance of this level of education in lying the foundation for success in higher levels, access and participation in preprimary education in Tanzania is considerably low (Ten Met, 2009). The persistence of this situation may cause the children suffer emotionally, socially, intellectually and physically (Osakwe, 2009). The study done by Cosmas (2010) highlighted some challenges facing pre-primary education which included lack of instructional materials, lack of chairs and tables or desks, high enrolment in some schools, low enrolment in some schools, absence of classroom(s)/buildings for pre-school pupils, low quality preprimary education, shortage and untrained pre-primary education teachers. One may wonder how education is being provided in the presence of such challenges. According to Mtahabwa (2007), no single study has been done to examine the link between policy and practice at the pre-primary school level. As a result, there has been lack of knowledge about the pre-primary educational policy implementation. More specifically, there is a dearth of knowledge on how teachers in the public pre-primary schools facilitate children's learning within the constraints of the macro and micro contexts. Through this background so far, issues on pre-primary education in Tanzania are not well highlighted and emphasized, it is the intention of this study to put more emphasis on issues associated with pre-primary education provision in Tanzania.

\section{Statement of the Problem}

Many schools in Tanzania were observed to lack pre-primary streams; many teachers and educational stakeholders were complaining about the poor quality of preprimary education with a number of unknown reasons (URT, 2001; Mtahabwa, 2007; 
Pambas, 2010; Cosmas, 2010). However, these studies did not show clearly issues associated with the provision of pre-primary education. Being the case the issues based on pre-primary education in Tanzania need not to be disregarded and therefore, this study examined these issues for the better provision of pre-primary education in Tanzania.

\section{Purpose of the Study}

The purpose of this study was to examine the issues in the provision of preprimary education in Tanzania through a critical diagnostic analysis to identify the challenges, and possible strategies towards addressing the identified issues.

\section{Specific Objectives}

The following were the specific objectives of the study:

a) To assess the current practices in the provision of pre-primary education in Tanzania in relation to the ETP(1995);

b) To investigate the challenges that encounter provision of pre-primary education in Tanzania; and

c) To suggest appropriate strategies toward provision of pre-primary education in Tanzania.

\section{Methodology}

The study was conducted in Monduli district whereby ten (10) Government primary schools were randomly selected among fifty six schools in the district. These schools were selected due to the fact that it would provide the relevant information needed in the study. Purposive sampling technique was used to get 10 ward education coordinators. These participants were included in the sample study because they were directly implementing educational objectives and are the day-to-day supervisors Purposive sampling technique was used to get 10 heads of schools. These participants were included in the study because they were directly implementing educational objectives and are the day-to-day supervisors of the schools in their wards. A simple random sampling was used to get teachers, a total of ten (10) of pre-primary school teachers were involved in the study but only eight pre-primary teachers were found.

In this study two, (2) district educational officials were selected on the basis of purposeful sampling technique. The District School Inspectors (DSI's) were also involved in this study. Three (3) school inspectors were used as sample for this study. Purposive sampling was used to get the District school inspectors. They were selected because they had mandatory administration on the schools on behalf of the Government. Research tools used in this study include questionnaires, interviews, observations and documentary review. 
AFRREV, 10 (1), S/NO 40, JANUARY, $2016 \mid$

\section{Results and Discussion}

\section{Current Practices in the Provisions of Pre-primary Education in Government Primary Schools in Tanzania}

Observations results show that out of ten (10) schools which were observed, 5 $(50 \%)$ of the schools contained pre-primary education, while $5(50 \%)$ had not. The information obtained through interviews conducted with educational officers revealed that out of 10 schools researched, 5 primary schools delivered pre-primary education. In connection to that, the pre-primary schools lack qualified teachers causing pupils to be taught with unqualified teachers. This implies that the provision of pre-primary education was near to the ground in some schools as verified through the findings. This is in line with UNESCO (2005) which affirmed that education is a right of every one and emphasis should base on pre-primary education which is the foundation for other levels of education. Thus, be it the Government or other education entities is credential to provide all necessary facilities towards effective provision of pre-primary education (URT, 1995).

Through observation, some visited schools contained pre-primary classrooms while $7(70 \%)$ did not have pre-primary classrooms. This shows that there are few schools which contained pre-primary classrooms. This is in line with URT (2012b) which indicated that many primary schools still lack pre-primary classes and other adequate facilities including toilets. One of the interviewed teachers had the following to say: "... lack or insufficient classrooms lead to poor provision of education especially for the pre-primary classes contrary to the other classes in the school...." This finding is in line with URT (2008) asserts that, in Tanzania, few primary schools have a class to serve early childhood education. This indicates that little emphasis is placed towards the enhancement of such education for pupils' future effective learning. The combined lack of teachers and classrooms has created a situation in which multi-grade teaching is required in a large number of classrooms. Of the 31,868 primary-school classrooms, 27.2 per cent were multi-grade (UNICEF CFS, 2011).

Accessibility of Teaching and Learning Materials were issues to be investigated whereby majority of schools 7 (70\%) do not have accessibility of teaching and learning materials, while $3(30 \%)$ schools were lucky to have the materials. The current findings are contrary to the statement which stated that large scale school effectiveness studies have highlighted the importance of textbooks and other learning materials on student performance. Jaiyeoba and Atanda (2005) hypothesize that educational facilities are those things which enable a skilful teacher to achieve a level of instructional effectiveness that far exceeds what is possible when they are not provided. The finding corresponds to the statement made by (BEST, 2011; URT 2011b) around 42 per cent of five and six year-old were enrolled in pre-primary schools in 2011. Other children attend informal community based child care centers. The majority

Copyright () IAARR, 2007-2016: www.afrrevjo.net

Indexed African Journals Online: www.ajo.info 
of pre-school classrooms lack supplies and play materials. One of the pre-primary teacher argued that "...lack of teaching and learning materials was a major challenge facing us daily..."

The finding is quite different from BRAC and Shahjamal (2008) who argued that, the teachers use various teaching aids to make lessons easier and attractive to the pupils. Some of the aids are provided by BRAC and some are made by the teachers and the students using local materials. BRAC provided teaching aids which include letter cubic (Bornerchokka), domino cards, textbooks, teacher guide, copybooks, pencils, erasers, sharpeners, English alphabet chart, scale, hardboard, etc. The locally-made materials include letter chart (bornerchart), number chart (shonkarchart), pot made of mud, mobile phone, oven, cake, plate, glass, rope, snake, dheki, doll, boat, ball, watch, sticks, etc. Locally-made materials have two purposes; firstly, to use those while teaching, and secondly to decorate the classroom.

This study revealed that most of the pre-primary schools lack qualified teachers causing pupils to be taught by unqualified teachers. The study found that only 1 out of 10 schools had a professional pre-primary teacher, while the rest 9 schools $(90 \%)$ had neither professional pre-primary teachers nor ordinary teachers who taught the preprimary schools/classes. Most of the respondents complained a lot that the Government is not serious with pre-primary education which is the foundation of other levels of education. During the interviews with pre-primary teachers, one of the teachers had this to say:

...I have told the head teacher that I am not competent to teach preprimary pupils, but he has been forcing me to teach instead of looking for the competent teachers out of the school, as a result I fail to deliver well education to learners...

The above argument concurs with the study done by Leu (2004) and URT (2001)which reported that most of the pre-primary schools in third world countries face challenges in provision of quality pre-primary education due to lack of qualified professional preprimary school teachers. Most of the school managers are blamed all the time by the Government and parents that education deteriorates in terms of quality in their schools without knowing that there is critical shortage of qualified teachers who are the engine for provision of quality education. No matter how effective initial teacher education is, continuous learning is essential in improving professional expertise in order to cope with changes in their areas of specialization (Meena, 2009; Mkonongwa, 2012; Shahjamal, 2008). Available literature associates the shortage of in-service training with the lack of funds to run the programmes (Kitta, 2004). 
Findings through documentary review whereby the researcher examined pupil's enrolment for three consecutive years in pre-primary education. It was revealed that the school and students' enrollment was poor due to the distance from home to the school, as well as negative attitude held by their parents who don't like the children to be involved in the pre-primary schools education. The findings are in line with (BEST, 2012; URT,2012a) which states that, in Tanzania, the total enrolment in pre-primary education dropped by 3.2\% from 1,069,208 in year 2011 to 1,034,729 in year 2012 which implies that there is a decrease in participation in pre-primary education. The above argument concurs with a statement from one of head of schools who said that:

...Some pupils fail to come to school due to the presence of wild animals and lack of learned persons in the family, as well as (Ubaguzi) segregation of taking pupils to school due to polygamy style of life...

The current findings are also supported by the statement stated that pre-primary education did not get priority as it received for primary education to the world community. In Bangladesh, household level national surveys revealed that the net enrolment rate at primary level is nearly $87 \%$ but the rate is only $13.5 \%$ for pre-primary (Nath and Sylva, 2007).

\section{Challenges Encountered in the Provision of Pre-primary Education}

Findings of this study revealed that majority of the respondents $40(83 \%)$ agreed that distance from home to school was a problem facing the provision of preprimary education except for $8(17 \%)$ of the respondents who disagreed, $29(60 \%)$ of respondents agreed that schools do not offer pre-primary education in their area; while $19(40 \%)$ agreed, 44(92\%) of the respondent agreed that children are involved in domestic works contrary to $4(8 \%)$ who disagreed. $44(92 \%)$ of the respondents agreed that the society have negative attitude towards pre-primary education while4 (8\%) disagreed, $44(92 \%)$ of the respondents agreed that some parents neglect pre-primary education for young children whilst $4(8 \%)$ disagreed.45(94\%)of the respondents agreed that on inadequate infrastructures for pre-primary education except $3(6 \%)$ of respondents, $42(87 \%)$ of the respondents agreed that there was inadequate teaching and learning facilities unlike 6(13\%) of respondent, 38(79\%) of the respondents agreed on the insufficient fund to run pre-primary education contrary to10( $21 \%)$ of the respondents and $45(94 \%)$ who agreed that the society is not well informed about the importance of pre-primary education except $3(6 \%)$ of the respondents who disagreed. This is in line with UNICEF (2011) which revealed that one factor associated with poor provision of pre-schools and drop-out rates is during the early grades in an essence of the lack of school readiness especially for children whose first language is not the language of instruction.

The finding of the study shows that there was a critical shortage of teaching and learning facilities in most of the pre-primary schools. However, few schools were 
well equipped in terms of teaching and learning facilities. This was evidenced by $94 \%$ of this study's respondents who argued that pre-primary schools face a critical shortage of teaching and learning facilities except for $6 \%$ which had good facilities. One of the school teachers had this to say: "...I face a lot of problems during preparation for the lesson as I don't have even a single book to refer...." The findings are in line with Mbatha (2004) and Katz (1999) who observed that children in schools with critical shortage of teaching and learning resources require a lot of efforts from teachers to learn well than those in rich communities. One of the head teachers had this to explain when asked to comment about availability of teaching and learning resources in his school: "...My school has no reference books for teachers and pupils as a result teachers work day and night to find reference books in order to prepare lessons to teach..." This head teacher's arguments is in line with Schneider (2003) who asserts that inadequate teaching and learning facilities have a direct impact on teaching and learning to both teachers and pupils. Most of the school inspectors complained much on shortage of teaching and learning facilities in their schools as one of the major causes of poor provision of education. One of the school inspectors was quoted complaining that: "...Most of the schools inspected do not meet criteria for the provision of pre-primary education due to critical lack of teaching and learning resources..." His stance is supported by Yadar (2001) and the report by UNESCO (2008) which reported that inadequate teaching and learning materials such as textbooks, class rooms, teaching aids (chalk, board, ruler and protractor), stationeries and laboratories affect provision of education. This reflect that in many schools there are problems of desks for the pupils as well as insufficient teaching and learning materials because a pre-primary classroom should be well equipped with many learning materials.

It was also discovered that there was a critical shortage of teaching staff in most of the pre-primary schools, except for very few schools. This was evident through percentage comparison in which 6 schools out of $10(60 \%)$ had shortage of teachers and 4 out of $10(40 \%)$ had teachers to teach. Alos discovered was the fact that preprimary schools face critical shortage of teachers to provide education in pre-primary schools in Tanzania. The findings of this study are in line with the study done by UNICEF (1997) and Rice (2003) who argued that the presence of few teachers increases the teaching load resulting into failure to handle huge classes. This indicated that pre-primary schools are less supported by the Government and other education stakeholders to the extent that they failed to provide education to clients. Teachers are among the most important inputs into the educational system and, therefore, the presence of enough and qualified teachers is so fundamental in enhancing good provision of education in pre-primary schools in Tanzania.

However, in few schools, the situation was found different as schools were well equipped with enough and qualified teachers which enabled them to handle well their roles towards good provision of education in their schools. When respondents 
from those schools were asked as to why their schools face few challenges in the provision of education they responded that they were well supported with enough and qualified teachers. This agrees with Ayodo (2003) who affirmed that a teacher is the most influential factor affecting the learning characteristics of the pupils followed by textbooks. Therefore, for schools to ensure good provision of education, they need to be provided with enough and qualified teachers.

From the findings, it is evident that the Government and other educational stakeholders put less effort in providing fund to pre-primary schools.Most of the respondents said that pre-primary education is neglected to a large extent in such a way that it fails to provide education to clients. Moreover, it is very true that it is very difficult for pre-primary schools to provide quality education without having enough funds to access necessary resources. One head of pre-primary school argued that:

...I am tired promising my teachers that I will buy books for teaching and pay them overtime allowances as I did not receive any fund to run the school for almost three years from 2011-2013since I was appointed to run this school to date ...

This finding is in congruent with Makene (2007) who asserts that inadequate financial inputs usually hinder provision of instructional materials in schools for learners and teachers use. In addition to that, Baker and Elmer (2009) who affirm that schools that spend more money per pupil tend to have higher average outcomes. It means that, for pre-primary schools to provide education to pupils more funds is needed to support proper running of the schools.

\section{Necessary Strategies that should be undertaken to Ensure Smooth Running of Government Pre-Primary Education in Tanzania}

The findings of this study indicated that, majority of the respondents 46 (96\%) agreed to strategy that 'to establish pre-primary school sub-centres to the proximity of the pupils' homestead' except for 2 (4\%) of the respondents. This finding is in line with Bronfenbrenner (1979) who demonstrates that family involvement can be strengthened with positive results for young children and their school readiness. To achieve these results, it is necessary to match children's developmental needs, parents' attitudes and practices, and early childhood programs expectations and support of family involvement.

The study shows that $47(98 \%)$ of the respondents agreed with the statement 'to create community awareness on the importance of pre-primary education' is a good strategy while $1(2 \%)$ disagreed. The finding is corresponding to the statement made by UNESCO (2006) which affirmed that, for the education sector, pre-primary education is a natural entry point to early childhood provision. Pre-primary education deserves prioritization on the condition that it promotes the child's holistic development, which 
it is delivered in an environment meeting some minimum pedagogical standards and that there is a phased plan for the inclusion of younger age groups. So long as these preconditions are met, pre-primary education is the most realistic way for the education sector to approach the EFA declaration that learning begins at birth.

The study found that $48(100 \%)$ of the respondents strongly agreed with the suggestion that 'to upgrade and expand the pre-primary education infrastructures within the primary school premises could be a good strategy.' This finding was supported by UNESCO (2006) which pointed out that the provision options available for the education sector to support early childhood tend to favour pre-primary education. From the findings, it is evident that $47(98 \%)$ of the respondent also agreed to involve various stakeholders, such as religious organizations, NGOs, private organizations, etc. to invest in pre-primary education contrary to $1(2 \%)$ of the respondents.

URT, (2012b) Identified some Strategies to Increase Access and Equity at the Preprimary Education Level as Follows:

i) To ensure that every primary school has a pre-primary class with adequate facilities, including classrooms and latrines, for the provision of the two year pre-primary education cycle, taking account of children with special needs;

ii) To mobilize and support LGAs to set up satellite pre-primary classes in difficult and hard-to-reach areas;

iii) To sensitize LGAs to enforce by-laws in order to promote correct school-age enrolment in pre-primary education;

iv) To mobilize the private sector to continue supporting the provision of preprimary education;

v) To raise the awareness of the community on the importance of pre-primary education for all children, including those with special needs and;

vi) To mobilize the community to support school feeding for pre-primary children.

Available evidence suggests that early childhood education has a positive influence on educational development of children in later life and some writers on early childhood education have asserted that investing in it can yield high returns (Barnett 2006; Rolnick and Grunewald, 2003).The objectives of pre-primary education in the country can only be achieved if the policy is consistently and effectively implemented.

\section{Conclusion}

The results of this study concluded that the participants were aware with the current provision of pre-primary education and the pertaining issues; such as presence of pre-primary education, availability of pre-primary classrooms, accessibility of teaching and learning materials, availability of professional pre-primary teachers, in- 
service training of pre-primary teachers as well as enrolment. The study also revealed various factors, including distance from school to children homestead; pessimistic attitudes of the society towards education, negligence, inadequate facilities, scarcity of teachers, and unstable school feeding programs are the challenges faced provision of pre-primary education. Moreover, strategies to improve the provision of Pre-primary Education; first, was the government to involve various stakeholders such as Religious Organizations, NGOs, and Private Organizations to invest in pre-primary education. Second, is to upgrade and expand the pre-primary education infrastructures within the primary school premises. Third, is to create community awareness on the importance of pre-primary education as the government insisted that each primary school to launch a pre-primary class. Fourth, respondents strongly agreed to use by-laws against those parents who neglect pre-primary education as a strategy to improve the provision of pre-primary education.

\section{Recommendations for Action}

Based on the findings, recommendations were made that policy planners need to clarify the meaning of being prepared for pre-primary schooling, pre-primary classes need trained, qualified and permanently employed teachers. Also, the Government should provide subsidies to furnish pre-primary classes with relevant books, tables and chairs. Furthermore, pupils aged five years should have their own classrooms separate from those aged six years because they learn at different contents. Lastly, conceptions of policy and decision makers for pre-primary schooling in Tanzania need to be explored. On the subject of the research findings, the study also came up with the following recommendations:

i) To encourage the people to establish pre-primary school sub-centres to the nearness of the pupils' homestead, creating community consciousness (especially for traditional leaders) on the significance of pre-primary education (through meetings, seminars and advertisements).

ii) To improve and develop the pre-primary education facilities within the primary school premises, involving various stakeholders (such as public, private, and religious organizations).

iii) To invest in pre-primary education, constructing relevant regulations to use against those people who disregard pre-primary education, and motivating teachers through in-service or pre-service training on pre-primary education and beneficial teaching and learning environment.

iv) Early childhood education should be encouraged by the government by providing pre-primary educational facilities (classrooms, instructional materials, and equipment) needed for the success of the provision of education.

Moreover, quality education for pre-primary education should be improved through:

Copyright (C) IAARR, 2007-2016: www.afrrevjo.net

Indexed African Journals Online: www.ajo.info 
i) Training of supervisors on the uniqueness of pre-primary education and how to supervise both their teachers and schools.

ii) Providing guidelines on competency based Standard One entry qualification that include social, communication, confidence and the 3Rs

iii) Developing a community mobilization and awareness creation programme for parents and the general public on the benefits of pre-primary, their roles and responsibilities.

\subsubsection{Recommendations for Further Research}

On the basis of the study findings, the following recommendations are made for further research:

i) Further research should be conducted on the role of in-service training to preprimary school teachers in the provision of education.

ii) Also, a research on issues in the provision of pre-primary education at national level should be done since this study was confined at Monduli district only.

iii) The study also recommends for further research to be undertaken to assess the quality of pre-primary education offered in private primary schools and the government primary schools.

\section{References}

Ayodo T. M. O. (2003). Efficiency in Kenyan secondary schools. Paper Presented at the Annual Secondary School Heads' Association Conference in Uasin Gishu District on 2nd May 2002.

Baker, B. D. \& Elmer, D. R. (2009). The politics of off-the-shelf school finance reform. Educational Policy, Vol. 23, Iss.

Bronfenbrenner, U. (1979). The ecology of human development: Experiments by nature and design. Cambridge: Harvard University Press.

Cosmas, J. (2010). Challenges facing primary school heads in managing pre-primary school units subsumed within established Primary School Structures in Tanzania. Unpublished M.A Thesis, University of Dodoma.

Ei-ie.org (2008). Education international report 2008. From http://www.ei-ie.org (retrieved on September 10, 2013)

EFA Assessment (2000). Country reports: Tanzania (Mainland). Retrieved January 11, 2014, from http://www2.unesco.org/wef/countryreports/tanzania/contents.html 
Hallinger, P. (1992).The evolving role of American principals: From managerial to instructional to transformational leaders. Journal of Educational Administration, 30(3), 35-48.

Jaiyeoba, A. O. \& Atanda, A. I. (2005). Quality sustenance in Nigerian educational system: Challenges to government. In Akpa, G. O., Udoh, S. U. \& Fagbamiye, E. O. (eds.) Deregulating the provision and management of education in Nigeria. Jos: M. P. Gina Concept Ltd. 98-103.

Katz, L. G. (1999). International perspectives on early childhood education: Lessons from my travels. Early Childhood Research and Practice, 1(1), Retrieved October, 2013, from http://ecrp.uiuc.edu/vlnl/katz.html

Kitta, S. (2004). Enhancing mathematics teachers ' pedagogical content knowledge and skills in Tanzania. Enschede: University of Twente.

Leu, E. (2004).The patterns and purposes of school-based and cluster teacher professional development programmes. Working Paper \#2 under EQUIP1's Study of School-based Teacher In-service Programs and Clustering of Schools. U.S. Agency for International Development. Retrieved September, 2013, from http://www.equip123.net/docs/Workingp2.pdf

Louis, K. S. \& Miles, M. B. (1990). Improving the urban high school: What works and why. New York: Teachers' College Press.

Makene, M.W. (2004). The Effects of underfunding on performance of community secondary schools in Tanzania. Unpublished MA (Ed) Dissertation. Dar es Salaam: University of Dar es Salaam.

Mbatha, M.V. (2004). The principal's instructional leadership role as a factor influencing academic performance: A case study. MEd Dissertation. Pretoria: University of South Africa.

Meena, W. E. (2009). Curriculum innovation in teacher education: Exploring conceptions among Tanzanian teacher educators. Vasa: Abo Akademi University Press.

Mkonongwa, P. (2012). Quality education in Tanzanian context. A paper presented to the African Federation of Head of Schools' Conference Mlimani from 10th 13th, October, 2012.Retrieved from http://www.acp2012.or.tz/uploads/files/QUALITY\%20EDUCATION\%20IN \%20TANZANIAN $\% 20 \mathrm{CONTEXT} \% 20 \mathrm{~A} \% 20 \mathrm{PAPER} \% 20 \mathrm{PRESENTED} \% 20$ TO\%20THE\%20AFRICAN\%20FEDERATION\%20OF\%20HEAD\%20OF\% 20SCHOOLS.pdf). Site visited on 10/10/ 2013 
Mtahabwa, L. (2007). Pre-primary educational policy and practice in Tanzania: Observations from urban and rural pre-primary schools. Unpublished $\mathrm{PhD}$ Thesis, University of Hong Kong.

Nath, S. R. \& Sylva, K. (2007). Children's access to pre-school education in Bangladesh. International Journal of Early Years Education 15 (3):275-95.

Osakwe, R.N. (2009). The effect of early childhood experience on the academic performances of primary school children. Benin City: Osasu Printing Press.

Pambas, T. (2010). Stakeholders' conception of young children's readiness for primary schooling in Tanzania. Unpublished M.A Thesis, University of Dodoma.

Rice, J. (2003). Teacher quality: Understanding the effectiveness of teacher attributes. Washington: Economic Policy Institute.

Rolnick, A. \& Grunewald, R. (2003). Early childhood development: Economic development with a high public return. Fedgazette, March 2003.

Schneider, M. (2003). Do school facilities affect academic outcomes? Washington: National Clearing house for Educational Facilities.

Shahjamal, M. M \&Nath, S. R. (2008). An evaluation of BRAC pre-primary education programme, Bangladesh: BRAC Centre (Published Research Report)

TEN/MET, (2009). Strengthening education in Tanzania: CSO contribution to the education sector reviews 2008 and 2009. Dar es Salaam: TEN/MET.

UNESCO (2000).Education for all: The Dakar framework for action. Dakar, Senegal. Retrieved December 4, 2013, from http://www.unesco.org/education/efa/edforall/framework.shtml

UNESCO (2006). Education for All: Literacy for life EFA global monitoring report 2006. Paris: UNESCO.

UNESCO (2007). EFA global monitoring report: strong foundations - early childhood care and education. Paris: UNESCO Publishing.

UNESCO/OECD (2005). Early childhood policy review project: The background report of Kenya. MOEST, Government of Kenya. Retrieved September, 2013, from

http://www.education.nairobiunesco.org/PDFs/ECD policy\%20review/Keny a\%20Earl y\%20Childhood\%20Background\%20Report.pdf

UNICEF CFS, (2011). Case study: Lao People's Democratic Republic, Vientiane. March 2011 
UNICEF, (1997).The state of the world's children 1997. Oxford: Oxford University press.

UNESCO (2008). National education support strategy: Lao PDR, 2008-2013', UNESCO, Bangkok, May 2008 (draft).

URT (1995).Tanzania Education and Training Policy. Dar es Salaam: MoEC.

URT (2001).Teacher education master plan: Medium term strategic and programme framework. Dar es Salaam.

URT (2008). The development of education: National report of the United Republic of Tanzania. Dar es Salaam.

URT (2011b). Basic education statistics in Tanzania. Dar es Salaam: MOEVT.

URT (2012a). Basic education statistics in Tanzania. Dar es Salaam: MOEVT.

URT (2012b). Ministry of Education and Vocational Training (MOEVT). Primary education development programme (PEDP) Phase III (2012-2016).

URT, (2013).2012. Population and Housing Census: Population Distribution by Administrative Areas. Dar es Salaam: National Bureau of Statistics.

Yadar. K. (2001). Teaching of life sciences. New Delhi: Anmol Publication. Ltd.

Table 1: Ward education coordinators (R1), Head of schools (R2), Pre-primary teachers (R3) and Primary teachers (R4)' responses on issues facing Preprimary education.

\begin{tabular}{|c|c|c|c|c|c|c|c|c|c|c|c|}
\hline \multirow{3}{*}{ Items no } & \multirow{3}{*}{ 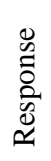 } & \multicolumn{4}{|c|}{ Respondents } & \multirow{2}{*}{\multicolumn{2}{|c|}{ R3 }} & \multirow{2}{*}{\multicolumn{2}{|c|}{$\mathrm{R} 4$}} & \multirow{2}{*}{\multicolumn{2}{|c|}{ Total }} \\
\hline & & R1 & & $\mathrm{R} 2$ & & & & & & & \\
\hline & & f & $\%$ & $\mathrm{f}$ & $\%$ & f & $\%$ & $\mathrm{f}$ & $\%$ & $\mathrm{f}$ & $\%$ \\
\hline \multirow{2}{*}{$\begin{array}{l}\text { Distance from } \\
\text { home to school }\end{array}$} & $\mathrm{T}$ & 9 & 90 & 8 & 80 & 7 & 88 & 16 & 80 & 40 & 83 \\
\hline & $\mathrm{F}$ & 1 & 10 & 2 & 20 & 1 & 12 & 4 & 20 & 8 & 17 \\
\hline \multirow{2}{*}{$\begin{array}{l}\text { Schools do not } \\
\text { offer preprimary } \\
\text { education in our } \\
\text { area }\end{array}$} & $\mathrm{T}$ & 5 & 50 & 6 & 60 & 7 & 88 & 11 & 55 & 29 & 60 \\
\hline & $\mathrm{F}$ & 5 & 50 & 4 & 40 & 1 & 12 & 9 & 45 & 19 & 40 \\
\hline \multirow{2}{*}{$\begin{array}{l}\text { Children are } \\
\text { involved in } \\
\text { domestic works } \\
\text { first }\end{array}$} & $\mathrm{T}$ & 9 & 90 & 9 & 90 & 7 & 88 & 19 & 95 & 44 & 92 \\
\hline & $\mathrm{F}$ & 1 & 10 & 1 & 10 & 1 & 12 & 1 & 5 & 4 & 8 \\
\hline \multirow{2}{*}{$\begin{array}{l}\text { The society has } \\
\text { negative attitude } \\
\text { towards pre- }\end{array}$} & $\mathrm{T}$ & 9 & 90 & 10 & $\begin{array}{l}10 \\
0\end{array}$ & 8 & $\begin{array}{l}10 \\
0\end{array}$ & 17 & 85 & 44 & 92 \\
\hline & $\mathrm{F}$ & 1 & 10 & 0 & 0 & 0 & 0 & 3 & 15 & 4 & 8 \\
\hline
\end{tabular}


AFRREV, 10 (1), S/NO 40, JANUARY, 2016

\begin{tabular}{|c|c|c|c|c|c|c|c|c|c|c|c|}
\hline \multicolumn{12}{|l|}{$\begin{array}{l}\text { primary } \\
\text { education }\end{array}$} \\
\hline Some parents & $\mathrm{T}$ & 10 & 100 & 9 & 90 & 7 & 88 & 18 & 90 & 44 & 92 \\
\hline $\begin{array}{l}\text { neglect pre- } \\
\text { primary } \\
\text { education }\end{array}$ & $\mathrm{F}$ & 0 & 0 & 1 & 10 & 1 & 12 & 2 & 10 & 4 & 8 \\
\hline \multirow{2}{*}{$\begin{array}{l}\text { No adequate } \\
\text { infrastructures } \\
\text { for pre-primary } \\
\text { education }\end{array}$} & $\mathrm{T}$ & 9 & 90 & 9 & 90 & 8 & $\begin{array}{l}10 \\
0\end{array}$ & 19 & 95 & 45 & 94 \\
\hline & $\mathrm{F}$ & 1 & 10 & 1 & 10 & 0 & 0 & 1 & 5 & 3 & 6 \\
\hline \multirow{2}{*}{$\begin{array}{l}\text { Inadequate } \\
\text { teaching and } \\
\text { learning } \\
\text { facilities }\end{array}$} & $\mathrm{T}$ & 8 & 80 & 7 & 70 & 7 & 88 & 20 & $\begin{array}{l}10 \\
0\end{array}$ & 42 & 87 \\
\hline & $\mathrm{F}$ & 2 & 20 & 3 & 30 & 1 & 12 & 0 & 0 & 6 & 13 \\
\hline \multirow{2}{*}{$\begin{array}{l}\text { Insufficient fund } \\
\text { to run pre- } \\
\text { primary } \\
\text { education }\end{array}$} & $\mathrm{T}$ & 7 & 70 & 8 & 80 & 8 & $\begin{array}{l}10 \\
0\end{array}$ & 15 & 75 & 38 & 79 \\
\hline & $\mathrm{F}$ & 3 & 30 & 2 & 20 & 0 & 0 & 5 & 25 & 10 & 21 \\
\hline \multirow{2}{*}{$\begin{array}{l}\text { The society is } \\
\text { not well } \\
\text { informed about } \\
\text { the importance } \\
\text { of pre-primary } \\
\text { education }\end{array}$} & $\mathrm{T}$ & 10 & 100 & 9 & 90 & 7 & 88 & 19 & 95 & 45 & 94 \\
\hline & $\mathrm{F}$ & 0 & 0 & 1 & 10 & 1 & 12 & 1 & 0 & 3 & 6 \\
\hline
\end{tabular}

Source: Field Data (2014)

Key: $\mathbf{f}=$ frequency, $\%=$ percentage, $\mathbf{T}=$ True, $\mathbf{F}=$ False 